\title{
EDUCATING PEOPLE WITH SPECIAL NEEDS IN THE VOLGA FEDERAL DISTRICT
}

\author{
EDUCANDO PESSOAS COM NECESSIDADES ESPECIAIS NO DISTRITO FEDERAL \\ DE VOLGA
}

\section{EDUCANDO A LAS PERSONAS CON NECESIDADES ESPECIALES EN EL DISTRITO FEDERAL DE VOLGA}

\author{
Elena Anatolyevna KARASIK ${ }^{1}$ \\ Iuliia Vitalievna SEREGINA ${ }^{2}$ \\ Ramziya Nurgalievna GUBAYDULLINA ${ }^{3}$ \\ Ramil Haevich YAGUDIN ${ }^{4}$
}

\begin{abstract}
Special education is defined as the process of educating students in a way that provides accommodations that address their differences, disabilities, and special needs. Generally speaking, this process requires individually planned and systematically monitored teaching procedures, adjusted equipment and materials, and accessible settings. Nowadays, growing attention is being to paid to people with special needs. The study examines the issue of educating people with special needs. The paper presents the quantitative representation of persons with disabilities showing disability groups in Russia, age and gender composition of persons with disabilities in the Volga Federal district has been analyzed. The issues of education and employment of persons with special needs have also been assessed. The health self-evaluation has been studied as well.
\end{abstract}

KEYWORDS: Living standards. Persons with disabilities. Special needs. Special education. Education and employment.

RESUMO: A educação especial é definida como o processo de educar os alunos de uma forma que ofereça acomodações que atendam às suas diferenças, deficiências e necessidades especiais. De modo geral, esse processo requer procedimentos de ensino planejados individualmente e sistematicamente monitorados, equipamentos $e$ materiais ajustados e ambientes acessíveis. Hoje em dia, uma atenção crescente está sendo dada às pessoas com necessidades especiais. $O$ estudo examina a questão da educação de pessoas com necessidades especiais. $O$ artigo apresenta a representação quantitativa de pessoas com deficiência mostrando grupos com deficiência na Rússia, a composição de idade e gênero das pessoas com deficiência

\footnotetext{
${ }^{1}$ Kazan Federal University, Kazan - Russia. ORCID: https://orcid.org/0000-0001-6357-7622. E-mail: elenakarasik2012@yandex.ru

2 Kazan Federal University, Kazan - Russia. ORCID: https://orcid.org/0000-0002-2145-105X. E-mail: julia.seregina@mail.ru

3 Kazan Federal University, Kazan - Russia. ORCID: https://orcid.org/0000-0002-4316-0915. E-mail: Ramzia.Gubaidullina@kpfu.ru

4 Kazan Federal University, Kazan - Russia. ORCID: https://orcid.org/0000-0003-3180-1284. E-mail: rh65@mail.ru
} 
no distrito Federal de Volga foi analisada. As questões de educação e emprego de pessoas com necessidades especiais também foram avaliadas. A autoavaliação da saúde também foi estudada.

PALAVRAS-CHAVE: Padrões de vida. Pessoas com deficiência. Necessidades especiais. Educação especial. Educação e emprego.

RESUMEN: La educación especial se define como el proceso de educar a los estudiantes de una manera que proporcione adaptaciones que aborden sus diferencias, discapacidades y necesidades especiales. En términos generales, este proceso requiere procedimientos de enseñanza planificados individualmente $y$ monitoreados sistemáticamente, equipos y materiales ajustados y entornos accesibles. Hoy en día, se está prestando cada vez más atención a las personas con necesidades especiales. El estudio examina el tema de la educación de las personas con necesidades especiales. El documento presenta la representación cuantitativa de las personas con discapacidad mostrando los grupos de discapacidad en Rusia, se ha analizado la composición por edad y género de las personas con discapacidad en el distrito federal del Volga. También se han evaluado las cuestiones de la educación y el empleo de las personas con necesidades especiales. También se ha estudiado la autoevaluación de la salud.

PALABRAS CLAVE: Niveles de vida. Personas con discapacidad. Necesidades especiales. Educación especial. Educación y empleo.

\section{Introduction}

Special Needs Education is education for students with disabilities, considering their educational demands, which intends the full growth of their abilities and their independence and social participation. Living standards are the main indicator of social and economic development of the country, and its improvement is the most overriding challenge of state management. The financial funds allocated to the creation of conditions ensuring a decent life and free development of people are increasing annually (FAKHRUTDINOVA; KHARLAMOV; KHARLAMOVA, 2017). Social and economic characteristics are important not only for the assessment of the quality of life and the situation in society, but also for the study of patterns and trends in relation to such a social group as people with special needs. Along with that, it must be noted that the existing reporting forms do not allow for an expanded and comprehensive analysis of living standards of persons with disabilities (PWD) since state statistical reporting does not meet the requirements for disability statistics as set out in the Convention on the Rights of Persons with Disabilities and regulatory instrument by United Nations. The Russian version assumes the use of such normative documents as the forms of the 
Ministry of Public Health (Form 19 "Information on Disabled Children"), the Pension Fund of Russia (No. 94 "Information on the Number of Pensioners and the Amount of Pensions Granted to Them"), the Ministry of Labor and Social Protection (the most important are No. 7"Information on Medical and Social Expertise of Persons Aged 18 and Older" and No. 7-D "Information on Medical and Social Expertise of Children under the Age of 18"). They are formed based on narrow departmental goals, and therefore, the indicators given in them are not sufficient to study the quality of life of PWD. More specifically, the forms are designed in such a way that the demographic characteristics of persons with disabilities do not usually overlap within and between them. In addition, there is a complete lack of information on the social characteristics of them. Besides departmental forms of statistical recording of persons with disabilities, there are specialized forms (in education, health care, social protection, physical education, and sport). Case study of sectoral state and municipal forms of registration of services, contingent and social support measures for persons with disabilities shows that, despite rather advanced legislation concerning persons with disabilities in the Russian Federation, forms of sectoral statistical monitoring are poorly related to it. They monitor the issues of services provision, social support measures and the quota (population) served - all that is the functionality of certain departments - in order to make decisions on specific tasks.

\section{Methods}

Describing the concept of "living standards" it is necessary to represent its constituent elements, their grouping into separate components, measurement methods, as well as the forming of integral models reflecting the living standards.

Currently, official statistics characterize the situation with disabilities in our country as follows: according to the Ministry of Health, there are almost 12 million persons with disabilities. The grouping of persons with disability is presented in Table 1 .

The most important requirement to the management to assess the quality of life in Russia is compliance with the range of analytical tasks being solved based on its practical application. It is necessary for governing bodies to develop appropriate regional economic and social policies aimed at eliminating the most acute regional disproportions and gradually reducing differentiation of the country's regions in terms of living standards in them. It should make it possible to adequately assess and compare the quality of life in Russian regions, monitor its dynamics, and conduct factor analysis of positive and negative changes in this area. 
Table 1 - The total number of persons with disability by groups

\begin{tabular}{|c|c|c|c|c|c|c|c|}
\hline & 2013 & 2014 & 2015 & 2016 & 2017 & 2018 & 2019 \\
\hline $\begin{array}{c}\text { Total disabled, } \\
\text { thousand people }\end{array}$ & 13082 & 12946 & 12924 & 12751 & 12261 & 12111 & 11947 \\
\hline $\begin{array}{c}\text { including: } \\
\text { First group }\end{array}$ & 1496 & 1451 & 1355 & 1283 & 1309 & 1466 & 1433 \\
\hline Second group & 6833 & 6595 & 6472 & 6250 & 5921 & 5552 & 5356 \\
\hline Third group & 4185 & 4320 & 4492 & 4601 & 4395 & 4442 & 4488 \\
\hline Disabled children & 568 & 580 & 605 & 617 & 636 & 651 & 670 \\
\hline $\begin{array}{c}\text { Total number of } \\
\text { persons with } \\
\text { disabilities, } \\
\text { per 1000 people } \\
\text { of the population }\end{array}$ & 91,3 & 90,1 & 88,4 & 87,0 & 83,5 & 82,5 & 81,4 \\
\hline
\end{tabular}

Source: Prepared by the authors ${ }^{5}$

The number of persons with disability in Privolzhsky (Volga) Federal District is shown in groups in Table 2 .

Table 2 - The number of persons with disabilities according to disability groups in the entities of the Privolzhsky (Volga) Federal District

\begin{tabular}{|c|c|c|c|c|c|c|c|}
\hline & Total & First group & $\begin{array}{c}\text { Second } \\
\text { group, third } \\
\text { degree }\end{array}$ & $\begin{array}{c}\text { Third } \\
\text { group, } \\
\text { third } \\
\text { degree }\end{array}$ & $\begin{array}{c}\text { Second } \\
\text { group }\end{array}$ & $\begin{array}{c}\text { Third } \\
\text { group, } \\
\text { second } \\
\text { degree }\end{array}$ & $\begin{array}{c}\text { Third } \\
\text { group }\end{array}$ \\
\hline $\begin{array}{c}\text { Privolzhsky } \\
\text { (Volga) Federal } \\
\text { District }\end{array}$ & $2,216,811$ & 239,591 & 28,496 & 20 & $1,005,664$ & 241 & 942,799 \\
\hline $\begin{array}{c}\text { Republic of } \\
\text { Bashkortostan }\end{array}$ & 253,933 & 24,821 & 660 & 2 & 98,360 & 28 & 130,062 \\
\hline $\begin{array}{c}\text { Republic of } \\
\text { Mari El }\end{array}$ & 63,133 & 7,254 & 620 & 3 & 29,728 & 6 & 25,522 \\
\hline $\begin{array}{c}\text { Republic of } \\
\text { Mordovia }\end{array}$ & 69,978 & 7,656 & 2,689 & 1 & 26,831 & 2 & 32,799 \\
\hline $\begin{array}{c}\text { Republic of } \\
\text { Tatarstan }\end{array}$ & 284,451 & 28,433 & 12,127 & 1 & 124,084 & 36 & 119,770 \\
\hline $\begin{array}{c}\text { Udmurtian } \\
\text { Republic }\end{array}$ & 104,525 & 16,293 & 1,786 & 2 & 40,785 & 6 & 45,653 \\
\hline $\begin{array}{c}\text { Chuvash } \\
\text { Republic }\end{array}$ & 78,329 & 9,672 & 227 & 1 & 26,849 & 5 & 41,575 \\
\hline Perm Territory & 122,809 & 15,134 & 8 & 0 & 47,923 & 3 & 59,741 \\
\hline Kirov Region & 289,365 & 28,520 & 1,099 & 3 & 160,812 & 25 & 98,906 \\
\hline
\end{tabular}

${ }^{5}$ Available at: https://sfri.ru. Access: 10 Jan. 2021.

RPGE- Revista on line de Política e Gestão Educacional, Araraquara, v. 25, n. esp. 6, p. 3493-3506, Dec. 2021. e-ISSN:1519-9029 DOI: https://doi.org/10.22633/rpge.v25iesp.6.16104 


\begin{tabular}{|c|c|c|c|c|c|c|c|}
\hline $\begin{array}{c}\text { Nizhny } \\
\text { Novgorod } \\
\text { Region }\end{array}$ & 189,409 & 19,526 & 2,032 & 0 & 102,827 & 19 & 65,005 \\
\hline $\begin{array}{c}\text { Orenburg } \\
\text { Region }\end{array}$ & 96,644 & 12,154 & 1,819 & 0 & 33,066 & 8 & 49,597 \\
\hline Penza Region & 203,677 & 23,046 & 1,792 & 2 & 98,069 & 23 & 80,745 \\
\hline Samara Region & 211,579 & 18,797 & 914 & 1 & 109,513 & 47 & 82,307 \\
\hline Saratov Region & 136,921 & 16,668 & 2,553 & 2 & 63,674 & 22 & 54,002 \\
\hline $\begin{array}{c}\text { Ulyanovsk } \\
\text { Region }\end{array}$ & 112,058 & 11,617 & 170 & 2 & 43,143 & 11 & 57,115 \\
\hline
\end{tabular}

Source: the table is drawn up based on the Federal State Statistics Service (2017a; 2017b)

Over the last years, the level of adult primary disablement has been declining: in 2007 it had been 95.9 per 10,000 of the population, and by 2018 it had fallen to 56.6 (Social situation and living standards of the Russian population, 2017). Within recent years, the primary disability rate has decreased at all ages, especially among pensioners. The standardized primary disability rate confirms the trend towards its declining among adults. This coefficient for disability groups proves the findings of the data for this type of population: the proportion of milder disability assignments is increasing. If the highest rate in 2007-2011 was for persons with disabilities of the 2nd group, the rate of persons with minor disabilities from 2012 became higher with moderate disabilities (FSSS, 2017).

Early in 2018, there were 12.11 million officially registered persons with disabilities in Russia including 11.46 million people aged 18 and over (9.6\% of the adult population). The total number of persons with disabilities in the first group was 12.8 per cent, the second group had 48.4 per cent and the third group had 38.8 per cent. At the same time, the Ministry of Labor estimates the real scale of the target group of social policy for people with special health needs at the number of 40 million people (all groups of citizens with low mobility) (FSSS, 2017). The number of persons with disabilities and gender composition in the regions of the Volga Federal District for 2018 and 2019 is presented in Table 3.

Table 3 - The number of persons with disabilities and gender composition in the constituent entities of the Privolzhsky (Volga) Federal District

\begin{tabular}{|c|c|c|c|c|c|c|}
\hline & \multicolumn{3}{|c|}{2018} & \multicolumn{3}{c|}{2019} \\
\hline & Total & Men & Women & Total & Men & Women \\
\hline $\begin{array}{c}\text { Privolzhsky } \\
\text { (Volga) Federal } \\
\text { District }\end{array}$ & $2,248,944$ & 971,090 & $1,277,854$ & $2,216,811$ & 966,462 & $1,250,349$ \\
\hline $\begin{array}{c}\text { Republic of } \\
\text { Bashkortostan }\end{array}$ & 258,595 & 113,778 & 144,817 & 253,933 & 113,288 & 140,645 \\
\hline
\end{tabular}




\begin{tabular}{|c|c|c|c|c|c|c|}
\hline Republic of Mari El & 63,634 & 27,411 & 36,223 & 63,133 & 27,469 & 35,664 \\
\hline $\begin{array}{c}\text { Republic of } \\
\text { Mordovia }\end{array}$ & 70,581 & 31,354 & 39,227 & 69,978 & 31,363 & 38,615 \\
\hline $\begin{array}{c}\text { Republic of } \\
\text { Tatarstan }\end{array}$ & 285,420 & 127,169 & 158,251 & 284,451 & 127,379 & 157,072 \\
\hline $\begin{array}{c}\text { Udmurtian } \\
\text { Republic }\end{array}$ & 105,645 & 47,673 & 57,972 & 104,525 & 47,335 & 57,190 \\
\hline Chuvash Republic & 79,905 & 39,197 & 40,708 & 78,329 & 38,402 & 39,927 \\
\hline Perm Territory & 125,653 & 52,325 & 73,328 & 122,809 & 51,749 & 71,060 \\
\hline Kirov Region & 294,333 & 113,721 & 180,612 & 289,365 & 113,745 & 175,620 \\
\hline $\begin{array}{c}\text { Nizhny Novgorod } \\
\text { Region }\end{array}$ & 193,857 & 79,043 & 114,814 & 189,409 & 77,868 & 111,541 \\
\hline Orenburg Region & 96,908 & 44,823 & 52,085 & 96,644 & 45,199 & 51,445 \\
\hline Penza Region & 208,489 & 86,669 & 121,820 & 203,677 & 85,578 & 118,099 \\
\hline Samara Region & 215,644 & 93,170 & 122,474 & 211,579 & 92,134 & 119,445 \\
\hline Saratov Region & 137,542 & 64,390 & 73,152 & 136,921 & 64,423 & 72,498 \\
\hline Ulyanovsk Region & 112,738 & 50,367 & 62,371 & 112,058 & 50,530 & 61,528 \\
\hline
\end{tabular}

Source: the table is drawn up based on the Federal State Statistics Service (2017a; 2017b)

The total number of persons with disability contains $66 \%$ pensioners and $4 \%$ children (DEMYANOVA, 2017). If we analyze persons with disabilities in terms of gender and age, the share of women with disabilities is always higher (on average, $57 \%$ of women) than men with disabilities. This is explained by the fact that women in our country are slightly more numerous than men, and their life expectancy is higher than men's. Moreover, the absolute majority of women with disabilities (over $85 \%$ in 2018) belong to the older age group (over 55 years) that can be explained by the fact that health problems are more frequent at a later age with more careful attitude towards their health compared to men ${ }^{6}$.

Table 4 - Number of children with disabilities in entities of Privolzhsky (Volga) Federal District

\begin{tabular}{|c|c|c|c|}
\hline & Total & Disabled children & \% of the total \\
\hline Privolzhsky (Volga) Federal District & $2,248,944$ & 109,240 & 4.86 \\
\hline Republic of Bashkortostan & 258,595 & 16,310 & 6.31 \\
\hline Republic of Mari El & 63,634 & 2,575 & 4.05 \\
\hline Republic of Mordovia & 70,581 & 2,381 & 3.37 \\
\hline Republic of Tatarstan & 285,420 & 14,987 & 5.25 \\
\hline Udmurtian Republic & 105,645 & 5,919 & 5.6 \\
\hline Chuvash Republic & 79,905 & 4,597 & 5.75 \\
\hline Perm Territory & 125,653 & 4,249 & 3.38 \\
\hline Kirov Region & 294,333 & 12,038 & 4.09 \\
\hline
\end{tabular}

${ }^{6}$ More info: http://www.who.int. Access: 10 Jan. 2021.

RPGE- Revista on line de Política e Gestão Educacional, Araraquara, v. 25, n. esp. 6, p. 3493-3506, Dec. 2021. e-ISSN:1519-9029 


\begin{tabular}{|c|c|c|c|}
\hline Nizhny Novgorod Region & 193,857 & 9,271 & 4.78 \\
\hline Orenburg Region & 96,908 & 4,180 & 4.31 \\
\hline Penza Region & 208,489 & 9,501 & 4.56 \\
\hline Samara Region & 215,644 & 10,644 & 4.94 \\
\hline Saratov Region & 137,542 & 7,244 & 5.27 \\
\hline Ulyanovsk Region & 112,738 & 5,344 & 4.74 \\
\hline
\end{tabular}

Source: the table is drawn up based on the Federal State Statistics Service (2017a; 2017b)

Only $26 \%$ of people with disabilities of employable age do work. Thus, in 2006 the employment of persons with disabilities was $30.2 \%$; in 2016 it was $28.9 \%$ and the minimum employment among the people with disabilities reached $23 \%$ in 2012. On average, the gap between the level of employment of people with and without disabilities amounted to $42 \%$. Among the reasons for such low employment of persons with disabilities are: discrimination in hiring; disincentive effect of social support institutions on the labor supply and low demand for work of persons with disabilities; health problems that affect labor productivity and limit the choice of profession. The average income of persons with disabilities is also expected to be lower. On average, in the period from 2006 to 2018 the income of PWD was lower by about $15 \%$ than that of people without disabilities. In 2016, the average income of persons with disabilities was 1,8269 rubles per month while that of people without disabilities was 1,084 rubles per month. Thus, incomes of PWD statistically significantly differ from incomes of people without disabilities; within the general population these differences are in the range from 1186 to 2642 rubles per month.

The majority of PWD are in the second and third groups and together they account for 84 per cent of all persons with disabilities. There are 83.5 persons with disabilities for every thousand people in Russia. Meanwhile, the unemployment rate among people with disabilities aged $15-72$ is $18.3 \%$. Only $39 \%$ of persons with disabilities who had applied to employment in 2018 were employed. At the same time, 59\% of persons with disabilities of this age have professional training/vocational education, including $17 \%$ of higher education and those are 42\% who have secondary vocational education (FSSS, 2017). From 2003 to 2016, there are significantly more persons with disabilities who do not have secondary general education $(37 \%$ are in 2003 compared to $25 \%$ in 2016 for persons with disabilities and $24 \%$ and $18 \%$, respectively, for those without disabilities), indicating that the number of persons with disabilities with incomplete secondary education is decreasing at a higher rate than that of those without secondary education (FAKHRUTDINOVA; MENDELSON; ABUTALIPOVA, 2019). The proportion of persons with secondary education among persons with and without 
disabilities was almost equal between 2003 and 2016, ranging from 28-29\% in 2016. The difference between persons with and without disabilities with higher education increased between 2003 and 2016 and was about 6\% in 2016 (the share of persons with higher education among persons with disabilities in 2016 was $21 \%$, this index among non-disabled was 27\%) (BELYAEVA, 2014). The lower level of education can be explained by the level of physical health of PWD, lack of special or integrated programs for persons with disabilities in educational institutions, environmental barriers etc. But it should be noted that the level of education of persons with disabilities older than working age is higher than that of those who are now of working age. Representatives of the older age group have higher education by $5 \%$ more $^{7}$. Consequently, the desire and opportunities for higher education in this group have decreased and consequently there are more people with only general secondary and basic secondary education, especially in rural areas. Compared to the rest of the population, persons with disabilities have fewer resources to implement their work and take up a place in the labor market. The same lesser opportunities for persons with disabilities are recorded in the analysis of their activity in attending cultural events, such as theatres, cinemas, concerts, exhibitions etc. (FAKHRUTDINOVA; SHAMSUTDINOVA; RAMSIYA, 2019). According to figures, only in the frequency of church attendance, PWD were close to the rest of the respondents, $23.7 \%$ visited church in 2016. Those who are 15-29 years old differ from the majority of the disabled; they are more actively involved in entrainment events and are less likely to attend church. This age group of people with disabilities has almost the same opportunities to access the Internet as the average Russian population (about 70\% in 2016), that cannot be said about people older than working age and even those who are of working age: only $28 \%$ and $54 \%$ respectively had access to the Internet.

\section{Results and Discussion}

The health self-assessment is expected to show a shift towards low values by persons with disabilities. Among people without disability only about $6-11 \%$ rated their health as poor; most rated it as good (33-50\%) or average (44-54\%). Persons with disabilities were much more likely to rate their health as poor (52-64\%), while only a small proportion (2-4\%) reported good health. Nevertheless, quite a large number of PWD assessed their health as average (34-44\%). That is, we can say that a significant number of PWD do not consider themselves unhealthy

${ }^{7}$ More info: http://www.who.int. Access: 10 Jan. 2021. 
despite their functional limitations. When life satisfaction is analyzed, changes towards lower indexes are also noticeable among PWD. Dissatisfaction with life was mentioned by 41-60\% of persons with disability, and this indicator was constantly decreasing until 2014. Not persons with disability had this indicator at the rate of $22-44 \%$. $23-37 \%$ of those with disabilities and $33-55 \%$ of those without disabilities were satisfied with their lives. The share of people who estimate their life satisfaction as average is approximately equal in groups of those with and without disabilities $(17-23 \%$ for PWD, against $22-27 \%$ for those without). The rate of dissatisfaction with their financial situation was stated by $53-70 \%$ of PWD and 55-66\% of those without. The dissatisfaction with the financial situation of PWD was mentioned somewhat more often than of those without disabilities (16-30\% vs. 17-27\% respectively), even though on average the PWD receive less. This may be explained by the fact that PWD have an additional income in the form of invalidity/disability benefit and/or pension, and they have lower needs. Persons with disabilities of working age rarely, in one case out of ten, live alone. As a rule, 20 or 30-year-old PWD either live with their parents or have a spouse and minor children. The type of household determines the socio-economic status of a PWD, and the presence of children under 18 in the family is an increased risk of poverty for families with disabilities if access to the labor market is limited by their health condition. By retirement age, most PWD live separately from their children, either alone with their spouse or alone. In cohorts of sixty- and, specially, seventy-year-old couples, the proportion of families where both spouses have a disability is increasing. The proportion of households consisting entirely of persons with disabilities reaches 40 and $50 \%$ respectively at these ages. The situation of PWD of older age cohorts significantly depends on the amount of pension and other benefits and social support programs for this category of population. At the oldest age, 80 years and older, the share of persons with disabilities living with their adult children is increasing. Children take on the job of caring for elderly parents and provide parents with all possible assistance. Living alone with a PWD or with a spouse does not mean lack of assistance or lack of connections with children. $80-90 \%$ of PWD that are single or married have adult children living alone. Among all PWD who have children living in other households, $80 \%$ receive assistance from their children in the form of care during illness, household help, food purchases or cash transfers. Among the reasons why there is no support from children, most often, according to parents with disabilities, is the lack of need. In return, parents with disabilities often help their adult children themselves, that is $68 \%$. Here, assistance in raising grandchildren prevails in terms of frequency. Parents also help their children with money. Money transfers from the older generation to the younger one is more common than the opposite. For Russian households, the practice of supporting adult 
children by their parents is a common phenomenon, and as we see, parents' disability does not change the established behavior of generations. In general, there are active links between PWD and their adult children living separately. In 55\% of cases the help and support are mutual, 13\% of PWD only help their children, not receiving support in return.

According to the Integrated monitoring of the living conditions of the population (IMLCP-2016 survey), 16\% of persons with disabilities have a paid job or gainful occupation (as of the week preceding the survey). Among PWD of 30- and 40-year-old the share of employed persons reaches $27 \%$. At this age, mainly PWD with Group III disabilities are employed, almost half of them have an income from work. Persons with disabilities of Group II are less likely to work - 15\% (Table 5).

Table 5 - The proportion of persons with disabilities who have paid work or gainful occupation, by group, $\%$

\begin{tabular}{|c|c|c|c|c|}
\hline Age & First Group & Second Group & Third Group & Total \\
\hline $18-29$ years & 2,2 & 15,2 & 39,8 & 20,3 \\
\hline $30-39$ years & 8,6 & 14,6 & 47,4 & 26,7 \\
\hline $40-49$ years & 6,0 & 15,0 & 45,1 & 26,6 \\
\hline $50-59$ years & 2,9 & 13,4 & 32,3 & 21,0 \\
\hline $60-72$ years & 0,8 & 5,4 & 10,8 & 7,1 \\
\hline $18-72$ years & 3,1 & 9,7 & 26,2 & 15,7 \\
\hline
\end{tabular}

Source: Calculations by the author on the data of Integrated monitoring of the living conditions of the population - 2016

Every fifth unemployed respondents expressed his/her willingness to return to the labor market if they were offered a suitable job. This makes up 16\% of all PWD. It is almost as many as those who actually work. In other words, measures to create special jobs, promote employment of the PWD at home and their (re)training could double the inclusion of them in the labor market. At the same time, the potential to increase employment of PWD by the Russian definition is higher than that of the disabled by the UN approach that is again related to the differences in their age composition.

When a PWD reaches the official working age limit, they automatically (without personal application to the Pension Fund office) become a recipient of an old-age pension. According to the designated disability group, they continue to receive only single monetary payments, formally withdrawing from the recipients the disability pension. At the same time, 
the disability pension for persons with sufficient length of service is transformed into an oldage pension while other persons with disabilities are transferred to the social old-age pension. The exceptions are recipients of the state pension for disability due to military trauma, participants in the Great Patriotic War, residents of besieged Leningrad. However, the number of this category is small. These people are entitled to receive two pensions at the same time: the state disability pension and the old-age insurance pension.

Since the transformation of the disability pension into an old-age pension takes place without a citizen's request, people are poorly informed about this that is reflected in their answers to the question about the type of pension in continuous and sample surveys of the population. The problem of measuring the prevalence of disability through the issue of receiving a disability pension is important in terms of methodology. It is of interest because it is the only indicator of disability in Russian censuses. Having an official status of disability gives the right not only to receive a pension but also to rehabilitation programs, resort vouchers, medical supplies and medicines.

According to the Russian Academy of National Economy and State Service (RANESS) survey, $72 \%$ of adults with official disability status believe they receive a disability pension (MALEVA, 2017). Only 15\% of them have another type of pension, not a disability pension. In reality, the share of recipients of other pensions is much higher especially among the oldest age cohorts, but about $70-80 \%$ of people older than the age of economic activity ( 73 years and older) continue to consider themselves recipients of disability pensions. It is interesting to note that when answering the questionnaire not by the PWD themselves, but by one of their family members the accuracy of the data decreases since a family member is more often mistaken about the type of pension for an elderly PWD. According to the findings of the survey, people of working age noted receiving disability pensions in $55-62 \%$ of cases. Therefore, the issue of receiving a disability pension is poorly suited as an indicator of disability, and the telephone format of the survey minimizes the impact of the interviewer and the possibility of explanations and comments as opposed to personal interviews with the IMLCP paper questionnaire.

\section{Summary}

Thus, the analysis of the examples of sectoral state and municipal forms of registration of services, contingent and measures of social support of persons with disabilities shows: despite rather advanced legislation concerning PWD in the Russian Federation, the forms of sectoral statistical monitoring are little associated with it. Most persons with disabilities are in 
the second and third groups and together they account for 84 per cent of all persons with disabilities. There are 83.5 persons with disabilities for every 1,000 persons in the Russian Federation. However, the unemployment rate among persons with disabilities aged 15-72 is $18.3 \%$.

\section{Conclusions}

The authors reviewed the standards of living of persons with special health needs in the Privolzhsky (Volga) Federal District, identified regional features and interrelationships of indicators. In the Russian real life social policy, the issues of improving the quality of life of the population are more acute than ever including the importance of paying attention to ensuring comfortable living conditions for persons with special needs.

ACKNOWLEDGEMENTS: The work is performed according to the Russian Government Program of Competitive Growth of Kazan Federal University.

\section{REFERENCES}

BELYAEVA, L. A. Overcoming the tension of social space is the way to epy consolidation of society. Philosophical sciences, v. 6, p. 8-22, 2014.

DEMYANOVA, A. V. Low level of employment of disabled people in Russia is a result of discrimination? Economic Journal of the Higher School of Economics, v. 21, n. 3, p. 385411, 2017.

FAKHRUTDINOVA A. V.; MENDELSON V. A.; ABUTALIPOVA L. N. Competence Development For The Competitive Specialist Education. Revista San Gregorio, v. 34, p. 3946, 2019.

FAKHRUTDINOVA, A. V.; SHAMSUTDINOVA, D. V.; RAMSIYA, N. G. Paradigmatic methodology of civic culture formation process in young generation. Journal of Sociology and Social Anthropology, v. 10, n. 4, p. 198-202, 2019.

FAKHRUTDINOVA, E. V. et al. The development of the business environment in conditions of economic instability. В сборнике: Globalization and its Socio-Economic Consequences. 17th International Scientific Conference Proceedings, p. 413-420, 2017.

FEDERAL REGISTER OF PERSONS WITH DISABILITIES. Number of disabled [Electronic resource]. n./d. Available: https://sfri.ru/analitika/chislennost. Access: 08 May 2019. 
FEDERAL STATE STATISTICS SERVICE (FSSS). Health care in Russia. 2017: Statistics data. Moscow, 2017a.

FEDERAL STATE STATISTICS SERVICE (FSSS). Social situation and living standards of the population in Russia. Moscow, 2017b.

MALEVA, T. M. Disability and social situation of disabled people in Russia. Moscow: Publishing house "Delo". RANESS, 2017.

Social situation and living standards of the Russian population. Statistics data. Moscow, 2017.

WORLD HEALTH ORGANIZATION (WHO). Report on Persons with HIA. Available: http://www.who.int/disabilities/world_report/2017/report/ru. Access: 22 May 2018. 


\section{How to reference this article}

KARASIK, E. A.; SEREGINA, I. V.; GUBAYDULLINA, R. N.; YAGUDIN, R. H. Educating people with special needs in the Volga Federal District. Revista on line de Política e Gestão Educacional, Araraquara, v. 25, n. esp. 6, p. 3493-3506, Dec. 2021. e-ISSN:1519-9029. DOI: https://doi.org/10.22633/rpge.v25iesp.6.16104

Submitted: 11/04/2021

Required revisions: $25 / 08 / 2021$

Approved: $27 / 11 / 2021$

Published: 30/12/2021

Processing and publication by the Editora Ibero-Americana de Educação. Correction, formatting, standardization and translation.

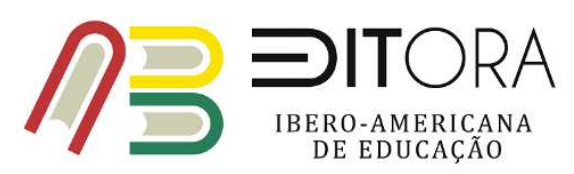

